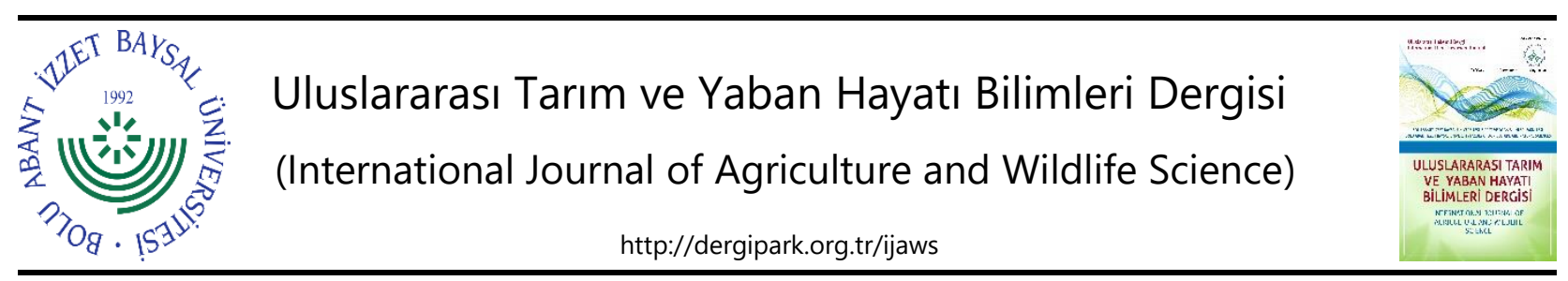

Araştırma Makalesi

\title{
Diyarbakır Ekolojik Koşullarında Kişniş (Coriandrum sativum var. microcarpum DC.) için Uygun Ekim Zamanı ve Ekim Normunun Belirlenmesi
}

\author{
Fethullah Tekin ${ }^{1}(\mathbb{D}) \quad \quad$ Tamer Eryiğit ${ }^{2 *}$ ， Murat Tunçtürk ${ }^{3}$ (D) \\ ${ }^{1}$ GAP Uluslararası Tarımsal Araştırma ve Eğitim Merkezi Müdürlüğü, Diyarbakır \\ ${ }^{2}$ Van Yüzüncü Yıl Üniversitesi, Gevaş MYO, Bitkisel ve Hayvansal Üretim Bölümü, Van \\ ${ }^{3}$ Van Yüzüncü Yıl Üniversitesi, Ziraat Fakültesi, Tarla Bitkileri Bölümü, Van
}

Geliş tarihi Received): 23.23.2021 Kabul tarihi (Accepted): 09.06.2021

\begin{abstract}
Anahtar kelimeler:
Kişniş (Coriandrum

sativum L.), ekim

zamanı, ekim normu

Özet. Bu çalışmada, Diyarbakır ekolojik koşullarında kişniş için uygun ekim zamanı ve ekim normunun belirlenmesi amaçlanmıştır. Coriandrum sativum microcarpum eko tipinden olan Denizli ekotipi materyal olarak kullanıldığı çalışma, tesadüf bloklarında bölünmüş parseller deneme deseninde dört tekerrürlü olarak yürütülmüştür. Denemede 4 ekim zamanı ve 4 ekim normu $\left(1,2,3\right.$ ve $\left.4 \mathrm{~kg} \mathrm{da}^{-1}\right)$ denenmiştir. Gözlem olarak tohum verimi, bitki boyu, toplam dal sayısı, biyolojik verim, bin dane ağırlığı ve hasat indeksi gözlemleri alınmıştır. Çalışma sonucunda elde edilen bulgulara göre farklı ekim zamanı uygulamaları sonucu oluşan tohum verimi 140.66 $171.47 \mathrm{~kg} \mathrm{da}^{-1}$, bitki boyu $66.37-70.60 \mathrm{~cm}$, bitkideki toplam dal sayısı 44.38 - 62.76 adet bitki-1, biyolojik verim $380.65-463.93 \mathrm{~kg} \mathrm{da}^{-1}, 1000$ dane ağırlığı $5.66-6.01 \mathrm{~g}$ ve hasat indeksi ise \%37.28 - 38.56 arasında değişmiştir. Farklı ekim normu uygulamaları ile oluşan tohum verimi 149.01 $156.67 \mathrm{~kg} \mathrm{da}^{-1}$, bitki boyu 67.47 - $69.45 \mathrm{~cm}$, bitkideki toplam dal sayısı 49.68 - 56.33 adet, biyolojik

*Sorumlu yazar tamyigit@hotmail.com verim 413.90 - $434.18 \mathrm{~kg} \mathrm{da}^{-1}, 1000$ dane ağırlığı 5.76 - $5.95 \mathrm{~g}$ ve hasat indeksi \%36.96 - 38.92 arasında değişmiştir. Sonuç olarak Diyarbakır ekolojik koşullarında kişniş için en uygun ekim zamanı sonbahar veya kışlık ekim (18 Ekim - 24 Aralık) ve en uygun ekim normunun ise $3 \mathrm{~kg} \mathrm{da}^{-1}$ olduğu tespit edilmiştir.
\end{abstract}

\section{Determination of Sowing Date and Norm for Coriander (Coriandrum sativum var. microcarpum DC.) in Diyarbakır Ecological Conditions}

\section{Keywords:}

Coriander (Coriandrum

sativum $\mathrm{L}$.), sowing

time, sowing norm

\begin{abstract}
In this study, it was aimed to determine the suitable sowing time and sowing norm for coriander in Diyarbakir ecological conditions. The study, in which Denizli ecotype, which is from Coriandrum sativum var. microcarpum ecotype, was used as a material, was carried out with four replications in split plots trial design in random blocks. In the Trial, 4 sowing time and 4 sowing norms $\left(1,2,3\right.$ and $\left.4 \mathrm{~kg} \mathrm{da}^{-1}\right)$ were tried. Seed yield, plant height, the total number of branches, biological yield, thousand-grain weight and harvest index were taken as observations. According to the findings obtained as a result of the study; as a result of different sowing time applications, it was observed that the plant height was $66.4-70.6 \mathrm{~cm}$, the total number of branches was $44.4-62.8$ pieces plant ${ }^{-1}$, the weight of 1000 grains was $5.8-6.0 \mathrm{~g}$, the seed yield was 142.4 - $171.5 \mathrm{~kg} \mathrm{da}^{-1}$, the biological yield was $380.6 .463 .9 \mathrm{~kg} \mathrm{da}^{-1}$, and the harvest index was ranged from 37.3 to $39.3 \%$. As a result of different sowing norm applications, it was determined that the plant height was 67.5 $69.4 \mathrm{~cm}$, the total number of branches was $49.7-56.3$, the weight of 1000 grain was $5.8-6.0 \mathrm{~g}$, the seed yield was 149.0 - $157.6 \mathrm{~kg} \mathrm{da}^{-1}$, the biological yield was $413.9-432.8 \mathrm{~kg} \mathrm{da}^{-1}$ and the harvest index was varied between $37.7-38.9 \%$. As a result, the most suitable sowing time for coriander in the ecological conditions of Diyarbakır is autumn or winter sowing (18 October - 24 December) and the most suitable sowing norm is 3 $\mathrm{kg} \mathrm{da}{ }^{-1}$.
\end{abstract}




\section{GíRiş}

Coriandrum sativum var. microcarpum alt türü Apiaceae familyasına mensup Coriandrum cinsinden Coriandrum sativum türüne ait tek yıllık ve otsu yapıdaki en önemli sebze, ilaç ve baharat bitkilerinden biridir (Davis, 1984). Linalool açısından zengin kişniş taneleri tıbbi bir bitki olarak (analjezik, gaz giderici, sindirim, temizleyici, anti-romatizmal ve anti-spazmodik) ve tatlandırıc olarak şekerleme yapımında, baharat olarak yemeklerde ve parfümeride kullanılmaktadır (Bhuiyan ve ark., 2009). Kişniş bitkisini yetiştirmenin başarısı birçok faktöre bağlıdır (Baydar, 2005). Kişniş verimi, çeşitlerin genetik özelliklerinden, iklim ve toprak koşullarından ve dahi agronomik faktörlerden önemli derecede etkilenmektedir. Bu nedenle, bu nedenle daha önce yapılmış birçok çalışma sonuçları arasında önemli farklılıklar görülebilmektedir. Agronomik bir faktör olan ekim tarihi, bitkilerin fotoperiyodik tepkisini etkilediğinden verimi belirleyen ana unsurlardan biridir. Ekim tarihi bitki büyümesinin ilk gelişim aşamasını etkilediği gibi aynı zamanda döllenmeyi ve dahi bitki gelişiminin sonraki aşamalarında gerçekleşen diğer olayları da etkiler. Gecikmiş bir ekim tarihi, sonraki gelişme aşamalarını hızlandırır ve bitkinin tüm büyüme süresini kısaltarak sürgünlerin yetersiz gelişimine (Carrubba ve ark., 2006) ve diğer verim bileşenlerinin düşmesine sebep olarak verimi düşürücü bir etki ortaya koyar (Zheljazkov ve ark., 2008).

Bir uzun gün bitkisi olan kişniş ekim zamanına bağlı olarak vejetasyon süresi 52-222 gün arasında değişebilmektedir (Özel ve ark., 2010). Geciken ekimlere bağı olarak vejetasyon süresi de düşmektedir. İlkbaharda yetiştirilenlerde büyüme süresi 90 ile 120 gündür (Ghobadi ve Ghobadi, 2010). Artan ışıklanma süresine ve sıcaklığa bağlı olarak vejetatif gelişmesini tamamlamadan generatif döneme geçebilmektedir. Bu durum bitkinin morfolojik gözlemlerinde kendini ortaya koymaktadır (Özel ve ark., 2009). Normal çevre ve yarı kurak Akdeniz koşullarında en yüksek tane verimine sonbahar-kış ekimlerinde sahip olduğu bilinmektedir (Carrubba ve ark., 2006).

Optimum seviyenin altındaki ekim normunun, bitkisel üretim girdilerinin kullanılabilirliği düzeyine bağlı olarak bu girdilerin kullanım verimliliğini, bitkisel verimi ve nihai anlamda üretici kârını azaltabilir. Fakat, optimumun üzerindeki bir ekim normunun ise üretim maliyetini, hastalık baskısını, böceklerin barınmasını artırarak verimi potansiyel olarak düşürmektedir. Sonuç olarak, verimi en üst düzeye çıkarmak için birim alan başına gereken minimum bitki sayısı olan agronomik optimum bitki yoğunluğunun (AOBY) tanımlanması, kişniş veriminde gelecekteki gelişmeler için çok önemlidir.

Bu çalışmada, Diyarbakır ekolojik koşullarında yetiştirilebilecek kişniş bitkisi için uygun ekim zamanı ve ekim normunun belirlenmesi amaçlanmıştır.

\section{MATERYAL VE METOT}

\section{Deneme Yerinin Iklim Özellikleri}

Denemenin kurulduğu alan Dicle Nehri kenarında, denizden yüksekliği 609 m ve 37²56'29.36"N enlem ile 40¹5'16.07"E boylamında yer almaktadır. Tipik Güneydoğu Anadolu iklim bölgesine sahip olup, yazları sıcak ve kurak, kışları ise nispeten soğuk ve yağışlı geçmektedir. Bu çalışmada denemelerin revize edildiği 2015, 2016, 2017 ve uzun yıllara (UY:1981-2017) ait aylık ortalama sıcaklık, toplam yağış ve nispi nem değerleri Şekil 1'de verilmiştir. 2015 ve 2016 yıllarında aylık ortalama sıcaklık değerlerinin uzun yıllara göre daha düşükken, 2017 yılı değerlerinin ise daha yüksek olduğu tespit edilmiştir. 2015 ve 2017 yılları Mart ve Nisan ayları hariç uzun yıllar ortalamasının oldukça altında aylık yağış değerlerine sahip olduğu saptanmıştır. 2017 yılııı Ocak ve Şubat ayları hariç tutulduğun her üç yılda da nispi nem miktarının uzun yıllar ortalamasına kısmen paralel gittiği, fakat Mart ve Nisan aylarında daha yüksek olduğu tespit edilmiştir (Şekil 1). 
Tekin ve ark., Diyarbakır Ekolojik Koşullarında Kişniş (Coriandrum sativum var. microcarpum DC.) için Uygun Ekim Zamanı ve Ekim Normu Belirlenmesi

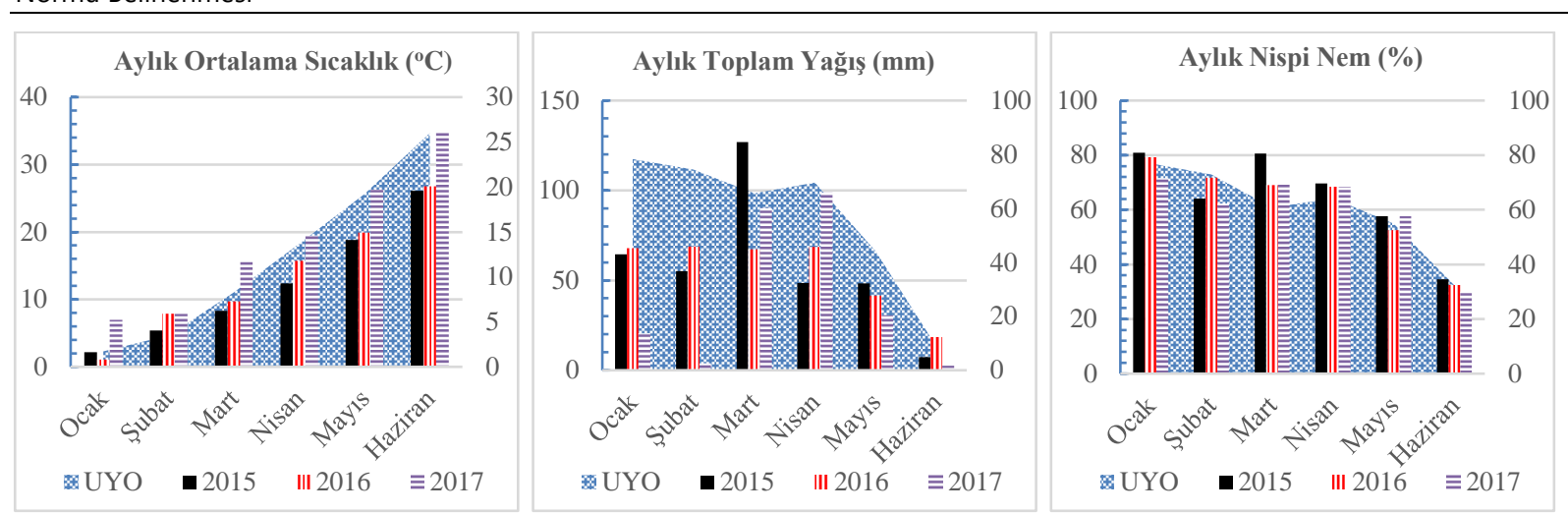

Şekil 1. Deneme her üç yılına ve Uzun Yıllara (UYO) ait aylık sıcaklık, aylık toplam yağış ve aylık nispi nem ortalama değerleri.

Figure 1. The monthly temperature, monthly total precipitation, and monthly relative humidity average values for each three years of the trial and Long Period (ALP).

\section{Deneme Yerinin Toprak Özellikleri}

Deneme sahasından alınan toprak numunelerinin yapılan analiz sonuçları Çizelge 1'de sunulmuştur. Deneme topraklarının \%73.18 su ile doygun, tuzsuz (\%0.03), bazik $(\mathrm{pH}=8.12)$, killi [kum oranı (\%27.12), kil oranı (54.10), silt oranı (18.75)], nem içeriği (\%32.67), porozite (\%47.88), kireç (\%8.02 $\left(\mathrm{CaCO}_{3}\right)$, fosfor $\left(1.35 \mathrm{~kg} \mathrm{da}^{-1}\right)$, potasyum $\left(92.27 \mathrm{~K}_{2} 0\right)$, organik madde $(\% 0.93)$, tarla kapasitesi (\%41.63), solma noktası (\%18.38), hacim ağırlığı (1.56 $\mathrm{g} \mathrm{cm}^{-3}$, özgül ağırlığı $\left(2.83 \mathrm{~g} \mathrm{~cm}^{-3}\right)$ ve KDK $\left(25.00 \mathrm{mg} 100 \mathrm{~g}^{-1}\right)$ sahip oluğu saptanmıştır (Çizelge 2).

Çizelge 1. Deneme yeri topraklarının bazı fiziksel ve kimyasal özellikleri.

Table 1. Some physical and chemical properties of trial field soils.

\begin{tabular}{|c|c|c|c|c|c|c|c|c|}
\hline $\begin{array}{c}\text { Toprağın } \\
\text { bünyesi }\end{array}$ & $\begin{array}{c}\text { Su ile } \\
\text { doyma } \\
(\%)\end{array}$ & $\begin{array}{c}\text { Tuz } \\
\text { içeriği } \\
(\%)\end{array}$ & pH & $\begin{array}{l}\text { Kum } \\
\text { (\%) }\end{array}$ & $\begin{array}{l}\text { Kil } \\
\text { (\%) }\end{array}$ & $\begin{array}{l}\text { Silt } \\
\text { (\%) }\end{array}$ & $\begin{array}{c}\text { Nem } \\
(\%)\end{array}$ & $\begin{array}{c}\text { Porozite } \\
\text { (\%) }\end{array}$ \\
\hline Killi & 73.18 & 0.03 & 8.12 & 27.12 & 54.10 & 18.75 & 32.67 & 47.88 \\
\hline $\begin{array}{c}\mathrm{CaCO}_{3} \\
\text { (\%) }\end{array}$ & $\begin{array}{c}\mathrm{P}_{2} \mathrm{O}_{5} \\
\left(\mathrm{~kg} \mathrm{da}^{-1}\right)\end{array}$ & $\begin{array}{c}\mathrm{K} 2 \mathrm{O} \\
\left(\mathrm{kg} \mathrm{da}^{-1}\right)\end{array}$ & $\begin{array}{c}\text { Organik } \\
\text { madde } \\
(\%)\end{array}$ & $\begin{array}{c}\text { Tarla } \\
\text { kapasitesi } \\
(\%) \\
\end{array}$ & $\begin{array}{c}\text { Solma } \\
\text { noktası } \\
(\%) \\
\end{array}$ & $\begin{array}{l}\text { Hacim } \\
\text { ağırlığı } \\
\left(\mathrm{g} \mathrm{cm}^{-3}\right)\end{array}$ & $\begin{array}{c}\text { Özgül } \\
\text { ağırlığı } \\
\left(\mathrm{g} \mathrm{cm}^{-3}\right)\end{array}$ & $\begin{array}{c}\text { KDK } \\
\left(\mathrm{me} 100 \mathrm{~g}^{-1}\right)\end{array}$ \\
\hline 8.02 & 1.35 & 92.27 & 0.93 & 41.63 & 18.38 & 1.52 & 2.83 & 25.00 \\
\hline
\end{tabular}

\section{Metot}

GAP Uluslararası Tarımsal Araştırma ve Eğitim Merkezi Müdürlüğü'ndeki deneme sahasında kurulan bu çalışma önceki yıllarda yapılan çalışmaların bir devamı niteliğinde tesadüf bloklarında bölünmüş parseller deneme desenine göre dört tekrarlamalı olarak 2015-2017 revize edilerek yeniden değerlendirilmiştir. Tarla denemesi GAP Uluslararası Tarımsal Araştırma ve Eğitim Merkezi Müdürlüğü'ndeki deneme alanında kurulmuştur. Denemede alt parsel büyüklükleri [3m (sıra uzunluğu) x 5 (sıra sayısı) $\times 0.45 \mathrm{~m}$ (sıra arası mesafe $(3 \times 5 \times 0.45)=] 6.75 \mathrm{~m}^{2 \prime}$ dir. Her alt ve ana parseller arasında $2.5 \mathrm{~m}$ ara bırakılmıştır.

Bölgede daha önce kişnişte ekim zamanı ile ilgili çalışma yapılmadığı için ekim zamanları aralığı biraz geniş tutulmuştur. Ekim zamanları iklim koşullarının el verdiği ölçüde Ekim ayından itibaren birer ay ara ile dört farklı ekim zamanda denenmiştir (Çizelge 3).

Çizelge 2. Denemenin kurulduğu ekim zamanları.

Table 2. The sowing times of the established trial.

\begin{tabular}{llll}
\hline Ekim zamanları & Birinci yetiştirme sezonu & i kinci yetiştirme sezonu & Üçüncü yetiştirme sezonu \\
\hline 1. Ekim Zamanı & 24 Kasım & 24 Kasım & 18 Ekim \\
2. Ekim Zamanı & 3 Ocak & 11 Ocak & 17 Kasım \\
3. Ekim Zamanı & 11 Şubat & 11 Şubat & 15 Ocak \\
4. Ekim Zamanı & 01 Mart & 10 Mart & 04. Mart \\
\hline
\end{tabular}


Denemede ekim zamanları ana parsellere ve dekara atılacak tohum miktarı ise alt parsellere yerleştirilmiş̧ir. Çalışmada, dört ekim normu; $1 \mathrm{~kg} \mathrm{da}^{-1}\left(170.36\right.$ adet $\left.\mathrm{m}^{-2}\right), 2 \mathrm{~kg} \mathrm{da}^{-1}$ (340.72 adet m $\left.\mathrm{m}^{-2}\right), 3$ $\mathrm{kg} \mathrm{da}^{-1}\left(511.07\right.$ adet $\left.\mathrm{m}^{-2}\right)$ ve $4 \mathrm{~kg} \mathrm{da}^{-1}\left(681.43\right.$ adet $\left.\mathrm{m}^{-2}\right)$ olacak şekilde ayarlanmıştır. Kullanılan kişniş tohumunun 1000 dane ağırlığı $5.87 \mathrm{~g}$ ve her bir alt parselin alanı $6.75 \mathrm{~m}^{2}$ olması hesabı ile metrekaredeki bitki sayısı hesaplanmıştır. Sonbaharda derin sürülen deneme alanı ekimden önce toprak tavını kaybetmeden kültivatör ile ikileme yapılmıştır. Arkasından kesekleri kırmak ve toprağı düzeltmek için diskaro ve merdane geçirilmiştir. Denemede tohumlar her parselde çepinle açılan çizilere $2-3 \mathrm{~cm}$ derinliğe düşecek şekilde elle ekilmiştir. Denemede azot dozu olarak $6 \mathrm{~kg} \mathrm{da}^{-1}$ olacak şekilde \%21'lik amonyum sülfat ve $4 \mathrm{~kg} \mathrm{da}^{-1}$ olacak şekilde \%46'lık triple süper fosfat ticari gübreleri kullanılmıştır. Fosforun tamamı azotun yarııı ekimle birlikte, azotun geri kalan yarısı da çiçeklenmeden önce verilmiştir. Özellikle ilk gelişme devresinde kişniş bitkisinin yabancı otlara karşı rekabeti çok zayıf olduğundan bu dönemde tüm yabancı otlar elle çekilmiştir. Bitki köklerinin hava almasını sağlamak, toprak kapilaritesini kırmak ve yapancı ot kontrolü için iki el çapası yapılmıştır. Birinci çapalama bitkiler çıkış yaptıktan sonra, ikincisi ise bitkiler 5-10 cm boylanınca yapılmıştır. Her üç deneme yılında da üretim sezonu kurak geçtiği için Mayıs ayının sonuna doğru ilave bir sulama yapılmıştır. Denemede her parselin kenarlarından birer sıra ve uç kısımlarından $0.5 \mathrm{~m}$ kenar tesiri bırakıldıktan sonra elle hasat edilmiştir. Hasat edilen bitkiler açık havada kurutulduktan sonra biyolojik verimi hesaplanmıştır. Kurutulan bitkiler sopa ile ezilerek harmanlanmıştır. Kaba saplar elle üsten ayıklanmıştır. Altta kalan harman önce eleklerden, daha sonra da savurma makinesinden geçirilerek tane ve sap birbirinden ayıklanmıştır.

\section{istatistiksel Analizler}

Çalışma sonucunda kaydedilen verilerin SPSS v 23.0 paket programı ile varyans analizi yapılmış ve elde edilen ortalamalar LSD çoklu karşılaştırma testine tabi tutularak gruplandırılmıştır. İncelenen özelliklerin birbiriyle ilişkilerini saptamak için de pearson korelasyon analizi yapılmıştır.

\section{BULGULAR VE TARTIŞMA}

Diyarbakır ekolojik koşullarında kişniş için uygun ekim zamanı ve ekim normu belirlenmesine yönelik yapılan çalışmada, bitki boyu, toplam dal sayısı, bin dane ağırlığı, tohum verimi, biyolojik verim ve hasat indeksi özellikleri Çizelge 3, 4 ve bu özellikler arasındaki korelasyonlara ilişkin veriler ise Çizelge 5 ve Şekil 2 verilmiştir.

\section{Bitki Boyu (cm)}

Farklı ekim zamanı ve ekim normu uygulamalarının belirlenmesine yönelik yürütülen bu çalışmada yılların iklim koşullarının farklılaşması kişnişte bitki boyu üzerinde istatistiksel olarak önemli $(P<0.01)$ farklılıkların oluşmasına sebep vermiş ve bunun sonucunda en yüksek bitki boyu değerinin üçüncü yılda $(81.0 \mathrm{~cm})$, en düşük bitki boyu değerinin $(54.1 \mathrm{~cm})$ ise ikinci yılda elde edilmiştir. Çalışma sonuçları bu yönüyle Kaya ve ark. (2000) ve (Özel ve ark., 2009) yapmış oldukları çalışma bulgularına benzerlik gösterdiği saptanmıştır. Farklı ekim zamanı uygulamalarının bitki boyu üzerine olan etkisi önemli $(P<0.01)$ çıkmış ve en yüksek bitki boyu değerlerinin birinci ve ikinci ekim zamanında $70.6 \mathrm{~cm}$ olarak ölçülürken en düşük bitki boyu ise üçüncü ve dördüncü ekim zamanlarında sırasıyla 67.7 ve $66.4 \mathrm{~cm}$ olarak gerçekleşmiştir (Çizelge 3). Bunun nedeni ise erken ekimlerde bitki fizyolojik olgunluğa erişmek için yeterli zamanı bulduğu için daha iyi boylanmıştır. Geç ekimlerde ise bitki vejetatif gelişmesini tamamlamak için yeterli zamanı bulmadığı için tam olarak boylanmamıştır (Kaya ve ark., 2000; Özel ve ark., 2009). Farklı ekim normları uygulamaları ile oluşan bitki boyu farkı istatistiki olarak önemli $(P>0.05)$ çıkmadığı ve bitki boyu değerlerinin 67.5-69.4 cm arasında değiştiği saptanmıştır (Çizelge 3). Yapılan benzer çalışmalarda, Tunçtürk (2006) dekara tohumluk miktarına göre bitki boyunun en seyrek ekimde $\left(1.5 \mathrm{~kg} \mathrm{da}^{-1}\right) 41.22 \mathrm{~cm}$, en sık ekimde $\left(3 \mathrm{~kg} \mathrm{da}^{-1}\right) 44.22 \mathrm{~cm}$; Moosavi ve ark. (2015) bitki sıklığına bağlı olarak bitki boyunun 35.6-40.7 cm arasında değiştiğini, Katar ve Kara (2016) en sık bitki sıklığında (50 bitki $\mathrm{m}^{-2}$ ) en yüksek bitki boyu elde ettiklerini bildirmektedirler. Bitki boyu açısından yıl $\mathrm{x}$ ekim zamanı ikili ve yıl x ekim zamanı x ekim normu üçlü interaksiyonlarını istatistiki olarak önemli $(P<0.01)$ olduğu saptanmıştır. Yıl x ekim zamanı interaksiyonunda en yüksek bitki boyu $(85.5 \mathrm{~cm})$ üçüncü yılda ve üçüncü ekim zamanında, en düşük tohum verimi $(48.6 \mathrm{~cm})$ ise ikinci yılda ve üçüncü ekim zamanında elde edilmiştir. Çizelge 3'te de görüldüğü gibi yıl x ekim zamanı x ekim normu üçlü interaksiyonlarında en 
Tekin ve ark., Diyarbakır Ekolojik Koşullarında Kişniş (Coriandrum sativum var. microcarpum DC.) için Uygun Ekim Zamanı ve Ekim Normu Belirlenmesi

yüksek bitki boyu değerinin $(92.7 \mathrm{~cm})$ üçüncü yılın üçüncü ekim zamanı ve birinci ekim normundan alınmıştır. Çalışma sonuçlarının Uzun ve ark. (2010) bulguları ile örtüştüğü tespit edilmiştir.

Çizelge 3. Kişnişte farklı ekim zamanı ve ekim normu uygulamaları sonucu elde edilen bitki boyu, toplam dal sayısı ve bin dane ağırlığı özelliklerine ilişkin üç yetiştirme sezonuna ait ortalama değerler ve oluşan LSD grupları.

Table 3. Average values of three growing seasons regarding plant height, total number of branches and weight of thousand kernels obtained as a result of different sowing time and sowing norm practices in coriander, and LSD groups formed.

\begin{tabular}{|c|c|c|c|c|c|c|c|c|c|c|c|c|c|c|}
\hline \multirow{2}{*}{\multicolumn{2}{|c|}{$\begin{array}{l}\text { Ekim } \\
\text { zamanı } \\
\text { (EZ) } \\
\end{array}$}} & \multirow{2}{*}{$\begin{array}{l}\text { Ekim } \\
\text { normu } \\
\text { (EN) }\end{array}$} & \multicolumn{3}{|c|}{ Bitki boyu $(\mathrm{cm})$} & \multicolumn{5}{|c|}{ Toplam dal sayısı (adet bitki-1) } & \multicolumn{4}{|c|}{ Bin dane ağırı̆̆ı (g) } \\
\hline & & & I. YıI & II. YıI & III. YıI & EZxEN & I. Yıl & II. Yıl & III. YıI & EZxEN & I. YıI & II. YıI & III. YıI & EZxEN \\
\hline \multirow{16}{*}{$\begin{array}{l}- \\
\mathbf{z} \\
\underset{x}{x} \\
\mathbf{N} \\
\mathbf{w} \\
\stackrel{x}{>}\end{array}$} & \multirow{5}{*}{$\overline{\mathbf{N}}$} & EN1 & 78.5a-f & $50.3 \mathrm{ij}$ & $79.7 \mathrm{a}-\mathrm{f}$ & 69.5 & 98.1ab & 104.1ab & $12.6 \mathrm{hi}$ & 71.6 & 5.9 & 6.0 & 5.9 & 5.9 \\
\hline & & EN2 & 82.1a-e & $46.9 i$ & $77.9 a-f$ & 69.0 & $75.9 b-f$ & $99.2 \mathrm{ab}$ & $12.7 \mathrm{hi}$ & 62.6 & 6.1 & 5.8 & 5.9 & 5.9 \\
\hline & & EN3 & $80.6 a-f$ & $57.1 \mathrm{~g}-\mathrm{j}$ & $85.7 \mathrm{a}-\mathrm{d}$ & 74.5 & $82.0 \mathrm{bc}$ & $96.5 \mathrm{ab}$ & $9.2 \mathrm{hi}$ & 62.6 & 6.2 & 6.0 & 6.1 & 6.1 \\
\hline & & EN4 & $76.0 \mathrm{~b}-\mathrm{g}$ & $56.5 g-j$ & $76.0 \mathrm{~b}-\mathrm{g}$ & 69.5 & $73.2 b-f$ & $78.4 \mathrm{~b}-\mathrm{e}$ & $11.4 \mathrm{hi}$ & 54.3 & 6.1 & 6.0 & 6.1 & 6.1 \\
\hline & & EN1 & $76.0 \mathrm{~b}-\mathrm{g}$ & 53.0ij & $80.3 a-f$ & 69.7 & $82.7 \mathrm{bc}$ & $49.9 \mathrm{~d}-\mathrm{g}$ & $14.0 \mathrm{hi}$ & 48.8 & 5.5 & 6.5 & 6.0 & 6.0 \\
\hline & \multirow{4}{*}{ N } & EN2 & $66.9 e-i$ & $68.2 \mathrm{e}-\mathrm{h}$ & $85.8 a-c$ & 73.6 & $61.8 c-f$ & $46.7 \mathrm{fg}$ & $13.3 \mathrm{hi}$ & 40.6 & 5.4 & 6.0 & 5.7 & 5.7 \\
\hline & & EN3 & $72.9 \mathrm{c}-\mathrm{g}$ & $57.4 \mathrm{~g}-\mathrm{j}$ & $77.9 a-f$ & 69.4 & $58.8 c-f$ & $62.2 c-f$ & $12.0 \mathrm{hi}$ & 44.3 & 5.6 & 6.3 & 5.9 & 5.9 \\
\hline & & EN4 & 69.1d-h & $56.4 h-j$ & $83.1 \mathrm{a}-\mathrm{d}$ & 69.5 & $58.6 \mathrm{c}-\mathrm{g}$ & $60.5 c-f$ & $12.3 \mathrm{hi}$ & 43.8 & 5.9 & 6.5 & 6.2 & 6.2 \\
\hline & & EN1 & 67.0e-h & $47.4 i$ & $92.7 \mathrm{a}$ & 69.0 & $82.1 \mathrm{bc}$ & $33.7 \mathrm{gh}$ & $13.9 \mathrm{hi}$ & 43.2 & 5.3 & 6.0 & 5.7 & 5.7 \\
\hline & \multirow{4}{*}{$\stackrel{\tilde{N}}{\mathbf{N}}$} & EN2 & $72.8 \mathrm{~d}-\mathrm{g}$ & $47.8 i$ & $83.4 \mathrm{a}-\mathrm{d}$ & 68.0 & $93.5 \mathrm{ab}$ & $50.5 \mathrm{~d}-\mathrm{g}$ & $9.8 \mathrm{hi}$ & 51.2 & 5.4 & 6.0 & 5.7 & 5.7 \\
\hline & & EN3 & $69.8 \mathrm{~d}-\mathrm{g}$ & $50.0 \mathrm{i}$ & $76.3 \mathrm{~b}-\mathrm{f}$ & 65.3 & $75.4 b-f$ & $47.9 \mathrm{e}-\mathrm{g}$ & $9.1 \mathrm{i}$ & 44.1 & 5.5 & 6.5 & 6.0 & 6.0 \\
\hline & & EN4 & 66.7e-h & $49.2 i$ & $89.9 \mathrm{ab}$ & 68.6 & $73.1 b-f$ & $58.3 \mathrm{c}-\mathrm{g}$ & $12.0 \mathrm{hi}$ & 47.8 & 5.3 & 6.8 & 6.0 & 6.0 \\
\hline & & EN1 & $65.1 f-i$ & $66.4 f-i$ & $77.2 \mathrm{v}-\mathrm{f}$ & 69.6 & $98.5 a b$ & $77.1 \mathrm{~b}-\mathrm{e}$ & $9.6 \mathrm{hi}$ & 61.7 & 5.7 & 6.8 & 6.2 & 6.2 \\
\hline & \multirow{3}{*}{$\underset{\mathbf{N}}{\mathbb{N}}$} & EN2 & $61.3 g-j$ & $55.2 \mathrm{ij}$ & $85.3 \mathrm{a}-\mathrm{d}$ & 67.3 & $95.5 a b$ & $46.7 \mathrm{e}-\mathrm{g}$ & $9.9 \mathrm{hi}$ & 50.7 & 5.7 & 5.8 & 5.7 & 5.7 \\
\hline & & EN3 & $66.5 e-i$ & $55.2 \mathrm{ij}$ & $77.4 \mathrm{~b}-\mathrm{f}$ & 66.4 & $86.9 b$ & $46.6 \mathrm{fg}$ & $9.7 \mathrm{hi}$ & 47.7 & 5.4 & 6.0 & 5.7 & 5.7 \\
\hline & & EN4 & $70.4 \mathrm{~d}-\mathrm{g}$ & $48.7 i$ & $67.8 \mathrm{e}-\mathrm{h}$ & 62.3 & 113.9a & $51.7 \mathrm{~d}-\mathrm{g}$ & $9.9 \mathrm{hi}$ & 58.5 & 5.3 & 6.3 & 5.0 & 5.5 \\
\hline \multicolumn{3}{|c|}{ Yıl Ort. " } & $71.3 \mathrm{~B}$ & $54.1 \mathrm{C}$ & $81.0 \mathrm{~A}$ & & $81.8 \mathrm{~A}$ & $63.1 \mathrm{~B}$ & $11.3 \mathrm{C}$ & & $5.6 \mathrm{~B}$ & $6.2 \mathrm{~A}$ & $5.9 \mathrm{AB}$ & \\
\hline
\end{tabular}

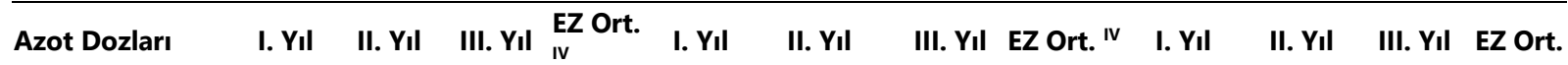

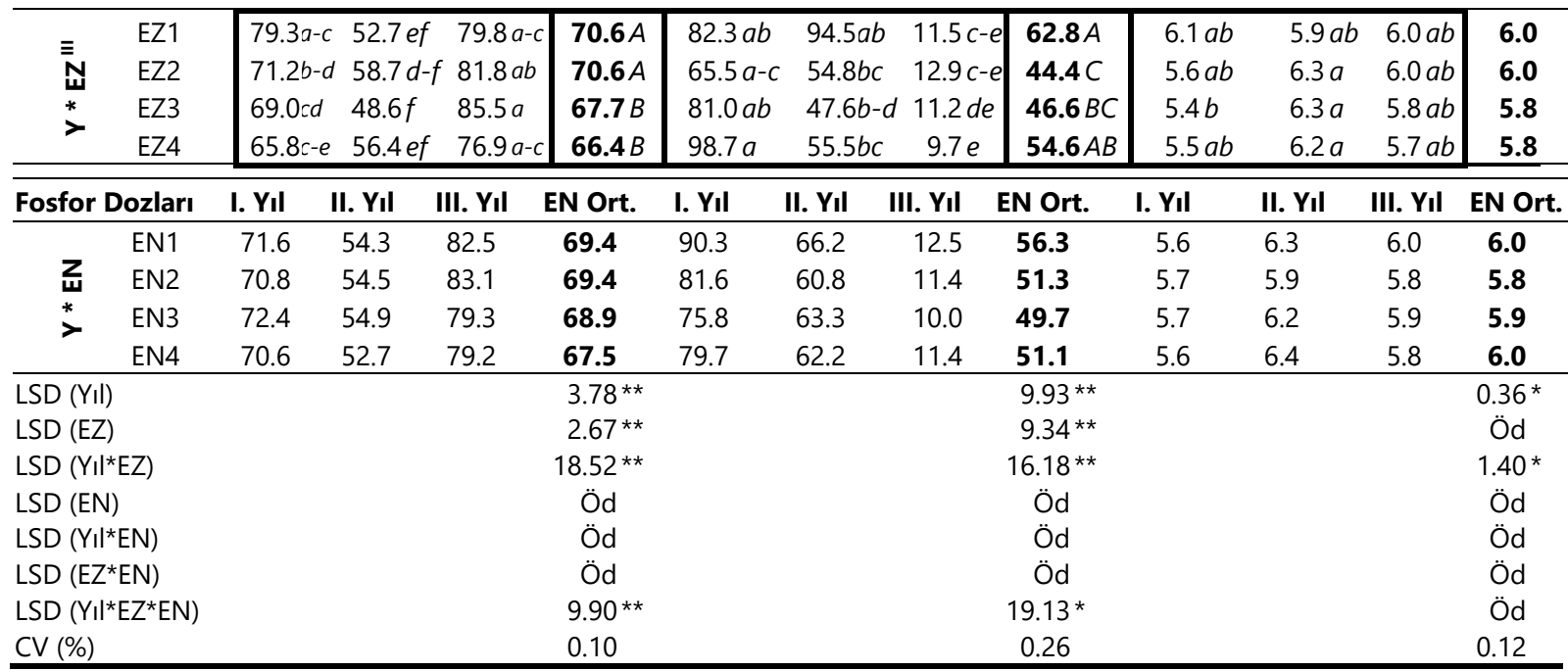

Öd: ístatistiksel olarak önemli değil (\%5)

*: Ortalamalar arasındaki farklılıklar \%5 düzeyinde önemli

**: Ortalamalar arasındaki farklılıklar \%1 düzeyinde önemli

': Her bir özellik için aynı küçük harfler ile gösterilen ortalamalar arasında fark yoktur.

II: Her bir özellik için aynı satırda aynı büyük harfler ile gösterilen ortalamalar arasında fark yoktur.

'I': Her bir özellik için aynı küçük italik harfler ile gösterilen ortalamalar arasında fark yoktur.

IV: Her bir özellik için aynı sütunda aynı büyük italik harfler ile gösterilen ortalamalar arasında fark yoktur

\section{Toplam Dal Sayısı (adet bitki-1)}

Çizelge 3'te görüldüğg̈ü üzere yılların kişnişte toplam dal sayısı üzerinde istatistiksel olarak önemli $(P<0.01)$ farklılıkların oluşmasına neden olduğu ve bunun neticesinde en yüksek toplam dal sayısı değerinin birinci yılda (81.8 adet), en düşük (11.3 adet) ise üçüncü yılda elde edilmiştir. Bitki boyu arttıkça dal sayılarında bir düşüşün yaşandığı görülmüştür. Benzer çalışmalar incelendiğinde, (Tunçtürk, 2006)

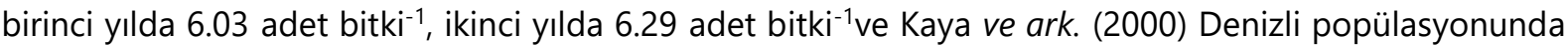
birinci yılda 5.6 adet bitki ${ }^{-1}$, ikinci yılda 6.3 adet bitki ${ }^{-1}$ arasında değiştiğini bildirmektedirler. Farklı ekim 
zamanlarının bitkideki toplam dal sayısına olan etkisi istatistiksel olarak çok önemli olmuş ve en fazla dal sayısı birinci ekim zamanında (62.8 adet), en az dal sayısı ise ikinci ekim zamanında (44.4 adet) elde edilmiştir. Benzer çalışmalarda genellikle ana dallar incelendiğinden sonuçlarının oldukça düşük olduğu görülmüştür. Kaya ve ark. (2000) Denizli popülasyonunda ilk ekim zamanında 4.9 adet bitki ${ }^{-1}$, son ekim zamanında 6.8 adet bitki ${ }^{-1}$ arasında değiştiğini bildirmektedirler. Farklı ekim normlarının bitkide toplam dal sayısı üzerine olan etkisi istatistiksel olarak önemsiz olduğu görülmüş ve toplam dal sayılarının 49.7 56.3 adet bitki ${ }^{-1}$ arasında değiştiği saptanmıştır (Çizelge 3). Tunçtürk (2006) yürüttüğü benzer bir çalışmada ekim normunun bitkideki ana dal sayısı üzerinde önemli etkilerinin olduğunu rapor etmişlerdir. Toplam dal sayısı üzerine yıl $x$ ekim zamanı ikili ve yıl $x$ ekim zamanı $x$ ekim normu üçlü interaksiyonlarının istatistiki olarak çok önemli etkilerinin olduğu saptanmıştır. Yıl x ekim zamanı interaksiyonunda en fazla dal sayısı değerinin (98.7 adet bitki ${ }^{-1}$ ) birinci yılda ve dördüncü ekim zamanında elde edilmişken, en az toplam dal sayısı değerinin (9.7 adet bitki ${ }^{-1}$ ) ise üçüncü yılda dördüncü ekim zamanında elde edilmiştir. Yıl x ekim zamanı x ekim normu üçlü interaksiyonunda en fazla dal sayısının (113.9 adet bitki ${ }^{-1}$ ) birinci yılda, dördüncü ekim zamanında ve $4 \mathrm{~kg} \mathrm{da}^{-1} \mathrm{ekim}$ normundan elde edilmiştir. En az toplam dal sayısının ise (9.10 adet bitki $\left.{ }^{-1}\right)$ ise üçüncü yılda, üçüncü eki zamanda ve $3 \mathrm{~kg} \mathrm{da}^{-1}$ ekim normundan elde edildiği saptanmıştır.

\section{Dane Ağırlı̆̆ (g)}

Çalışmada yıllara ait farklı iklim koşullarının kişnişte bin dane ağırlığına olan etkisinin istatistiki olarak önemli $(P<0.05)$ olduğu saptanmış ve en yüksek bin dane ağırlığının $(6.2 \mathrm{~g})$ denemenin ikinci yılından alındığı saptanmıştır. Denizli popülasyonu ile yapılan benzer bir çalışmada, Kaya ve ark. (2000) bin dane ağırlığını birinci yıl için $6.86 \mathrm{~g}$, ikinci yıl için ise $6.79 \mathrm{~g}$ olarak bildirmişlerdir. Çalışmada ekim zamanlarının bin dane ağılığı üzerinde istatistiksel olarak herhangi bir etkisinin olmadığı ve bin dane ağırlığı ortalama değerlerinin 5.8-6.0 g arasında değiştiği saptanmıştır (Çizelge 3). Özel ve ark. (2009) Mardin orjinli iri taneli bir kişniş ekotipi ile yaptıkları çalışmada bin dane ağırlığının 8.1-11.4 g arasında değiştiği bildirmektedirler. Çizelge 3'te görüldüğü gibi, farklı ekim normlarının kişnişte bin dane ağırlığı üzerine istatistiksel olarak önemli etkide bulunmadığı saptanmış ve bin dane ağırlığı ortalama değerlerinin 5.8$6.0 \mathrm{~g}$ arasında değiştiği gözlenmiştir. Tunçtürk (2006) tohumluk miktarına bağlı olarak 1000 dane ağırlığının da (sırası ile 11.86, 10.73, 10.88 ve $10.93 \mathrm{~g}$ ) değiştiğini bildirmektedir. Bin dane ağırlığı açısından yıl x ekim zamanı interaksiyonunun etkisinin istatistiki olarak önemli $(P<0.05)$ bulunmuş ve en yüksek bin dane ağırlığı ortalama değerinin ikinci yılda ikinci, üçüncü ve dördüncü ekim zamanlarında sırasıyla $6.3,6.3$ ve $6.2 \mathrm{~g}$ olarak elde edilmiştir. En düşük bin dane ağırlığı $(5.4 \mathrm{~g})$ ise birinci yılda üçüncü ekim zamanında elde edilmiştir.

\section{Tohum (meyve) Verimi ( $\left.\mathrm{kg} \mathrm{da}^{-1}\right)$}

Çizelge $4^{\prime}$ ten de görüldüğü gibi ekim zamanları ve ekim normları uygulamaları sonucu oluşan ortalama tohum veriminin yıllar itibariyle istatistiksel olarak önemli $(P<0.01)$ farklılıklar gösterdiği ve en yüksek tohum veriminin $\left(175.1,176.7 \mathrm{~kg} \mathrm{da}^{-1}\right)$ birinci ve üçüncü yılda, en düşük (110.6 kg da-1) ise ikinci yıldan elde edildiği saptanmıştır. Yıllar arasında oluşan tohum verimi farkının bu denli yüksek olmasının nedeni ikinci yılda yaşanan dolu zararından kaynaklandığı tespit edilmiştir. Farklılaşan iklim koşullarının tohum verimi üzerinde önemli etkilerinin olduğunu bildiren Özel ve ark. (2009) birinci yılda $174.16 \mathrm{~kg} \mathrm{da}$ 1, ikinci yılda $97.52 \mathrm{~kg} \mathrm{da}^{-1}$ ve Uzun ve ark. (2010) Uşak hattında yıllar arasındaki verim farkının 66.07$144.15 \mathrm{~kg} \mathrm{da}^{-1}$ arasında değiştiğini bildirmektedirler. Farklı ekim zamanları arasında oluşan tohum verimi farkı istatistiki olarak önemli $(P<0.01)$ bulunmuş ve en yüksek tohum verimi $\left(171.5 \mathrm{~kg} \mathrm{da}^{-1}\right)$ en erken ekimden, en düşük tohum verimi (142.4 $\mathrm{kg} \mathrm{da}^{-1}$ ) ise en geç ekim zamanında elde edilmiştir (Çizelge 4). Kaya ve ark. (2000) Denizli popülasyonunda en erken ekimde en yüksek tohum verimini $\left(94.0 \mathrm{~kg} \mathrm{da}^{-1}\right)$, en geç ekimde ise en düşük verimini $\left(55.1 \mathrm{~kg} \mathrm{da}^{-1}\right)$ elde ettiklerini bildirmektedirler. Çalışmada, farklı ekim normları arasında istatistiki olarak herhangi bir farkın olmadığı ve farklı ekim normu uygulamamaları sonucu oluşan tohum verimlerinin 149.0-156.8 $\mathrm{kg} \mathrm{da}^{-1}$ arasında değiştiği saptanmıştır (Çizelge 4). Çalışma sonuçları, meyve verimi için en uygun bitki sıklığının 50 bitki $\mathrm{m}^{-2}$ olduğunu bildiren Moosavi ve ark. (2015)'nın bulguları ile kısmen uyumludur. 
Tekin ve ark., Diyarbakır Ekolojik Koşullarında Kişniş (Coriandrum sativum var. microcarpum DC.) için Uygun Ekim Zamanı ve Ekim Normu Belirlenmesi

Çizelge 4. Kişnişte farklı ekim zamanı ve normu uygulamaları sonucu elde edilen tohum verimi, biyolojik verim ve hasat indeksi özelliklerine ilişkin üç yetiştirme sezonuna ait ortalama değerler ve oluşan gruplar.

Table 4. Average values of three growing seasons regarding seed yield, biological yield and harvest index properties obtained as a result of different sowing time and norm practices in coriander, and the groups formed.

\begin{tabular}{|c|c|c|c|c|c|c|c|c|c|c|c|c|c|}
\hline \multirow{2}{*}{$\begin{array}{l}\text { Ekim } \\
\text { zamanı } \\
\text { (EZ) }\end{array}$} & \multirow{2}{*}{$\begin{array}{l}\text { Ekim } \\
\text { normu } \\
\text { (EN) }\end{array}$} & \multicolumn{4}{|c|}{ Tohum verimi $\left(\mathbf{k g ~ d a}^{-1}\right)$} & \multicolumn{4}{|c|}{ Biyolojik verimi $\left(\mathrm{kg} \mathrm{da}^{-1}\right)$} & \multicolumn{3}{|c|}{ Hasat indeksi (\%) } & \multirow[b]{2}{*}{ EZXEN" } \\
\hline & & I. YıI & II. YII & III. YıI & EZxEN " & I I. YוI & II. YıI & III. YıI & EZxEN " & I. YıI & II. YıI & III. YıI & \\
\hline \multirow{16}{*}{$\begin{array}{l}\bar{z} \\
\mathbf{z} \\
\mathbf{x} \\
\mathbf{w} \\
\mathbf{x} \\
\mathbf{x}\end{array}$} & EN1 & 219.1a-d & $87.6 \mathrm{ij}$ & $144.3 \mathrm{e}-\mathrm{i}$ & $150.3 A B$ & 398.5 & 284.0 & 513.1 & 398.5 A-C & 39.0 & 28.2 & 33.6 & $33.6 \mathrm{AB}$ \\
\hline & EN2 & $261.6 a-c$ & $72.5 i$ & $168.2 \mathrm{~d}-\mathrm{g}$ & g $167.4 \mathrm{AB}$ & 387.2 & 197.5 & 577.0 & 387.2BC & 41.0 & 37.8 & 39.4 & 39.4 $A B$ \\
\hline & EN3 & 262.9ab & 118.4g-j & 169.0d-g & \begin{tabular}{l|l}
$g$ & $183.4 \mathrm{~A}$
\end{tabular} & 420.4 & 336.4 & 504.4 & $420.4 \mathrm{~A}-\mathrm{C}$ & 37.6 & 35.2 & 36.4 & 36.4 $A B$ \\
\hline & EN4 & 271.6a & $123.8 \mathrm{f}-\mathrm{j}$ & $158.8 d-h$ & h $184.7 \mathrm{~A}$ & 421.1 & 321.0 & 521.1 & $421.1 \mathrm{~A}-\mathrm{C}$ & 40.8 & 38.7 & 39.7 & $39.7 \mathrm{AB}$ \\
\hline & EN1 & 155.6e-h & $128.6 f-j$ & $160.0 d-g$ & g) $148.1 A B$ & 367.2 & 314.8 & 419.7 & $367.2 \mathrm{C}$ & 33.3 & 40.6 & 36.9 & $36.9 \mathrm{AB}$ \\
\hline & EN2 & $181.6 d-f$ & $135.8 \mathrm{f}-\mathrm{i}$ & 172.0d-g & g $163.1 \mathrm{AB}$ & 406.3 & 333.3 & 479.2 & $406.3 \mathrm{~A}-\mathrm{C}$ & 35.2 & 40.4 & 37.8 & $37.8 \mathrm{AB}$ \\
\hline & EN3 & 196.8de & $131.2 f-j$ & $150.4 \mathrm{e}-\mathrm{h}$ & h $159.5 \mathrm{AB}$ & 376.4 & 296.3 & 456.4 & $376.4 \mathrm{BC}$ & 38.5 & 44.8 & 41.6 & $41.6 \mathrm{AB}$ \\
\hline & EN4 & 191.4de & 107.0h-j & $153.2 \mathrm{e}-\mathrm{h}$ & h $150.5 \mathrm{AB}$ & 372.7 & 277.8 & 467.7 & 372.7BC & 37.5 & 37.3 & 37.4 & $37.4 \mathrm{AB}$ \\
\hline & EN1 & $144.4 \mathrm{e}-\mathrm{h}$ & $107.5 \mathrm{~h}-\mathrm{j}$ & $146.6 \mathrm{e}-\mathrm{h}$ & h $132.8 \mathrm{AB}$ & 399.9 & 271.6 & 528.2 & $399.9 \mathrm{~A}-\mathrm{C}$ & 35.8 & 43.2 & 39.5 & $39.5 \mathrm{AB}$ \\
\hline & EN2 & 151.1e-h & $87.6 \mathrm{ij}$ & 194.9de & 144.5 $A B$ & 498.5 & 234.6 & 762.5 & 498.5A-C & 34.1 & 35.6 & 34.8 & $34.8 \mathrm{AB}$ \\
\hline & EN3 & $159.9 \mathrm{~d}-\mathrm{g}$ & $98.5 \mathrm{ij}$ & 194.8de & $151.0 \mathrm{AB}$ & 437.7 & 228.4 & 647.0 & 437.7A-C & 35.3 & 43.0 & 34.8 & $37.7 \mathrm{AB}$ \\
\hline & EN4 & $140.7 f-i$ & 141.0f-i & $202.2 d$ & 161.3 $A B$ & 519.6 & 284.0 & 755.2 & $519.6 A$ & 31.1 & 49.9 & 40.5 & $40.5 \mathrm{AB}$ \\
\hline & EN1 & $120.0 \mathrm{~g}-\mathrm{j}$ & $164.3 \mathrm{~d}-\mathrm{g}$ & $210.1 b-d$ & d $164.8 \mathrm{AB}$ & 514.5 & 333.3 & 695.7 & 514.5 $\mathrm{AB}$ & 35.9 & 49.1 & 42.5 & $42.5 \mathrm{AB}$ \\
\hline & EN2 & $127.7 f-j$ & $96.2 \mathrm{ij}$ & 190.5de & 138.1 $A B$ & 439.1 & 209.9 & 668.4 & $439.1 \mathrm{~A}-\mathrm{C}$ & 42.2 & 45.1 & 43.7 & $43.7 \mathrm{~A}$ \\
\hline & EN3 & $119.9 g-j$ & $85.3 i$ & 203.7d & 136.3 $A B$ & 421.1 & 209.9 & 632.4 & 421.1A-C & 36.2 & 39.5 & 37.9 & $37.9 \mathrm{AB}$ \\
\hline & EN4 & $98.2 \mathrm{ij}$ & $85.2 i$ & $208.2 \mathrm{~cd}$ & 130.5 B & 387.2 & 222.2 & 607.7 & 405.7A-C & 32.4 & 37.2 & 30.2 & $33.3 \mathrm{~B}$ \\
\hline \multicolumn{2}{|l|}{ Yıl Ort."' } & $175.1 \mathrm{~A}$ & $110.6 \mathrm{~B}$ & 176.7 A & & $423.0 \mathrm{~B}$ & $272.2 \mathrm{C}$ & 577.2 A & & 36.6 & 40.4 & 37.9 & \\
\hline \multicolumn{2}{|c|}{ Azot Dozları } & I. YII & II. Y,I & III. YII & EZ Ort. & I. YII & II. YII & III. YII & $\begin{array}{l}\text { EZ Ort. } \\
\text { v }\end{array}$ & I. YıI & II. YII & III. YII & EZ Ort. \\
\hline \multirow{4}{*}{$\begin{array}{l}\geq \\
\text { N } \\
\stackrel{*}{>}\end{array}$} & EZ1 & $253.8 a$ & $100.6 e$ & $160.1 b-e$ & $171.5 \mathrm{~A}$ & $406.8 d$ & 284.7 ef & $528.9 b$ & $406.8 B$ & 39.6 & 35.0 & 37.3 & 37.3 \\
\hline & EZ2 & $181.3 b-d$ & $125.7 \mathrm{de}$ & 158.9b-e & $155.3 B$ & $380.6 \mathrm{de}$ & $305.6 e$ & $455.7 c$ & $380.6 B$ & 36.1 & 40.8 & 38.4 & 38.4 \\
\hline & EZ3 & $149.0 c-e$ & $108.6 e$ & $184.6 b c$ & $147.4 B C$ & $463.9 b c$ & $254.6 f$ & $673.2 a$ & $463.9 A$ & 34.1 & 43.0 & 37.4 & 38.1 \\
\hline & EZ4 & $116.4 e$ & $107.7 e$ & $203.1 a b$ & $142.4 C$ & $440.5 c d$ & $243.8 \mathrm{~g}$ & $651.0 a b$ & $445.1 A$ & 36.7 & 42.7 & 38.6 & 39.3 \\
\hline \multicolumn{2}{|c|}{ Fosfor Dozları } & I. YıI & II. YII & III. YII & EN Ort. & I. Yıl & II. YII & III. YıI & EN Ort. & I. YII & II. YII & III. YıI & EN Ort. \\
\hline \multirow{4}{*}{$\begin{array}{l}s \\
z \\
z \\
z\end{array}$} & EN1 & 159.8a-d & $122.0 \mathbf{b}-\mathbf{e} 1$ & $165.3 \mathrm{a}-\mathrm{c}$ & 149.0 & 420.1 cd & $300.9 d$ & $539.2 \mathbf{b}$ & 420.1 & 36.0 & 40.3 & 38.1 & 38.1 \\
\hline & EN2 & $180.5 \mathbf{a b}$ & 98.0 e $\quad 1$ & 181.4 ab & 153.3 & $432.8 c$ & $243.8 f$ & $621.8 \mathrm{a}$ & 432.8 & 38.1 & 39.7 & 38.9 & 38.9 \\
\hline & EN3 & $184.9 a$ & 108.3de 1 & 179.5 ab & 157.6 & 413.9 cd & 267.7 ef & $560.1 \mathrm{ab}$ & 413.9 & 36.9 & 40.6 & 37.7 & 38.4 \\
\hline & EN4 & 175.5ab & 114.3c-e 1 & 180.6 ab & 156.8 & $425.1 \mathrm{~cd}$ & 276.2 e & $587.9 \mathrm{ab}$ & 429.8 & 35.4 & 40.8 & 37.0 & 37.7 \\
\hline \multicolumn{2}{|c|}{ LSD $(Y, I)$} & & & & 9.76 ** & & & & $39.15^{\star *}$ & & & & Öd \\
\hline \multicolumn{2}{|l|}{ LSD (EZ) } & & & & 5.59 ** & & & & $11.07^{\text {** }}$ & & & & Öd \\
\hline \multicolumn{2}{|c|}{ LSD (Yıl*EZ) } & & & & $19.69 * *$ & & & & $54.71^{\star \star}$ & & & & Öd \\
\hline \multicolumn{2}{|c|}{ LSD (EN) } & & & & Öd & & & & Öd & & & & Öd \\
\hline \multicolumn{2}{|c|}{ LSD (Yı॥EN) } & & & & $18.01^{\text {** }}$ & & & & $38.72^{* *}$ & & & & Öd \\
\hline \multicolumn{2}{|c|}{ LSD $\left(E Z^{\star} E N\right)$} & & & & $20.8^{* *}$ & & & & $47.70^{\star \star}$ & & & & $5.40 * \star$ \\
\hline \multicolumn{2}{|c|}{ LSD $\left(Y_{I} I^{\star} E Z^{\star} E N\right)$} & & & & 35.98 ** & & & & Öd & & & & Öd \\
\hline \multicolumn{2}{|c|}{ CV (\%) } & & & & 0.17 & & & & 0.13 & & & & 0.17 \\
\hline
\end{tabular}

Öd: İstatistiksel olarak önemli değil (\%5)

**: Ortalamalar arasındaki farklııklar \%1 düzeyinde önemli

': Her bir özellik için aynı küçük harfler ile gösterilen ortalamalar arasında fark yoktur.

II. Her bir özellik için aynı sütunda aynı büyük harfler ile gösterilen ortalamalar arasında fark yoktur.

III: Her bir özellik için aynı satırda aynı büyük harfler ile gösterilen ortalamalar arasında fark yoktur.

Iv: Her bir özellik için aynı küçük italik harfler ile gösterilen ortalamalar arasında fark yoktur.

v: Her bir özellik için aynı sütunda büyük italik harfler ile gösterilen ortalamalar arasında fark yoktur.

vi: Her bir özellik için aynı satırda aynı küçük koyu harfler ile gösterilen ortalamalar arasında fark yoktur.

Araştırma sonucunda, tohum verimi açısından yıl x ekim zamanı, yıl x ekim normu, ekim zamanı $x$ ekim normu ikili ve yıl $x$ ekim zamanı $x$ ekim normu üçlü interaksiyonlarının istatistiki olarak önemli $(P<0.01)$ olduğu tespit edilmiştir. Buna göre yıl $x$ ekim zamanı interaksiyonunda en yüksek tohum verimi (253.8 $\mathrm{kg} \mathrm{da}^{-1}$ ) birinci yılda ve birinci ekim zamanında, en düşük tohum verimi (100.6 kg da $\left.{ }^{-1}\right)$ ise ikinci yılda ve birinci ekim zamanında elde edilmiştir (Çizelge 4). Yıl x ekim normu interaksiyonunda, en yüksek tohum verimi (184.9 $\mathrm{kg} \mathrm{da}^{-1}$ ) birinci yılda ve üçüncü ekim normunda elde edilirken en düşük tohum verimi ise ikinci yılda $\left(98.0 \mathrm{~kg} \mathrm{da}^{-1}\right)$ ve ikinci ekim normunda elde edilmiştir. Ekim zamanı x ekim normu interaksiyonunda en yüksek tohum verimi $\left(183.4,184.7 \mathrm{~kg} \mathrm{da}^{-1}\right)$ birinci ekim zamanında ve üçüncü ve dördüncü ekim normlarında saptanırken en düşük tohum verimi (1130.5 $\mathrm{kg} \mathrm{da}^{-1}$ ) dördüncü ekim 
zamanında ve dördüncü ekim normunda saptanmıştır. Yıl x ekim zamanı $\mathrm{x}$ ekim normu üçlü interaksiyonunda en yüksek tohum verimi $\left(271.6 \mathrm{~kg} \mathrm{da}^{-1}\right)$ birinci yılın dördüncü ekim zamanı ve dördüncü ekim normundan elde edilmiştir. En düşük tohum verimi $\left(72.5 \mathrm{~kg} \mathrm{da}^{-1}\right)$ ise ikinci yılın birinci ekim zamanı ve ikinci ekim normundan tespit edilmiştir (Çizelge 4).

\section{Biyolojik Verim (kg da-1)}

Çizelge 4'te, yıllara göre oluşan biyolojik verim farkının istatistiki olarak önemli $(P<0.01)$ olduğu tespit edilmiş ve en yüksek biyolojik verim $\left(577.2 \mathrm{~kg} \mathrm{da}^{-1}\right)$ üçüncü yılda, en düşük (272.2 $\left.\mathrm{kg} \mathrm{da}^{-1}\right)$ ise ikinci yılda ölçülmüştür. Çalışma sonucunun, Denizli popülasyonu ile yaptıkları çalışmada biyolojik verimin farklı iklim koşulları sergileyen yıllar itibariyle önemli ölçüde farklılaştığını bildiren Kaya ve ark. (2000)'nın bulgularıyla uyumlu olduğu tespit edilmiştir. Çizelge 4'te görüldüğü gibi farklı ekim zamanı uygulamaları sonucu oluşan biyolojik verimler arasında istatistiki olarak önemli $(P<0.01)$ farklılıkların olduğu saptanmış ve en yüksek biyolojik verimin $\left(463.9,445.1 \mathrm{~kg} \mathrm{da}^{-1}\right)$ üçüncü ve dördüncü ekim zamanlarında, en düşük biyolojik verim $\left(406.8,380.6 \mathrm{~kg} \mathrm{da}^{-1}\right)$ ise birinci ve ikinci ekim zamanlarında tespit edilmiştir. Çalışma sonuçları, farkı zamanlarda yapılan ekimler sonucu biyolojik verim arasında istatistiki düzeyde önemli farklııkların oluşabileceğini bildiren Kaya ve ark. (2000)'nın bulgularını destekler niteliktedir. Farklı ekim normu etkilerinin biyolojik verim üzerinde istatistiki olarak önemli olmadığı ve biyolojik verim ortalama değerlerinin 420.1-429.8 $\mathrm{kg} \mathrm{da}^{-1}$ arasında değiştiği saptanmıştır (Çizelge 4). Yıl x ekim zamanı, yıl x ekim normu ve ekim zamanı $x$ ekim normu ikili interaksiyonları sonucu biyolojik verimler arasında istatistiki olarak önemli $(P<0.01)$ farklılıkların olduğu tespit edilmiştir. Yıl $x$ ekim zamanı interaksiyonunda en yüksek biyolojik verim (673.2 $\left.\mathrm{kg} \mathrm{da}^{-1}\right)$ üçüncü yılda ve üçüncü ekim zamanında, en düşük tohum verimi (243.8 $\mathrm{kg} \mathrm{da}^{-1}$ ) ise ikinci yılda ve dördüncü ekim zamanında elde edilmiştir. Yıl x ekim normu interaksiyonunda en yüksek biyolojik verim $\left(621.8 \mathrm{~kg} \mathrm{da}^{-1}\right)$ üçüncü yılda ve ikinci ekim normundan elde edilirken en düşük biyolojik verim $\left(243.8 \mathrm{~kg} \mathrm{da}^{-1}\right)$ ise ikinci yılda ve ikinci ekim normundan elde edilmiştir. Ekim zamanı x ekim normu interaksiyonunda en yüksek biyolojik verim $\left(519.6 \mathrm{~kg} \mathrm{da}^{-1}\right)$ üçüncü ekim zamanında ve dördüncü ekim normundan, en düşük biyolojik verim $\left(367.2 \mathrm{~kg} \mathrm{da}^{-1}\right)$ üçüncü ekim zamanında ve birinci ekim normundan elde edilmiştir (Çizelge 4).

\section{Hasat indeksi (\%)}

Çalışmada yıllara, ekim zamanlarına, ekim normuna, ekim zamanı x ekim normunu hariç ikili ve üçlü interaksiyonlara ait hasat indeksleri ortalama değerleri arasında istatistiksel olarak herhangi bir farklığın olmadığı saptanmıştır. Yıllara ait hasat indeksi ortalama değerlerinin \%36.6-40.4 arasında, farklı ekim zamanlarına ait hasat indeksi \%37.3-39.3 arasında, farklı ekim normlarına ait hasat indeksleri ise \%37.738.9 arasında değiştiği saptanmıştır. Ekim zamanı x ekim normu interaksiyonuna ait hasat indeksi ortalama değerleri arasında istatistiksel olarak çok önemli $(P<0.01)$ farklılıklar tespit edilmiş ve en yüksek hasat indeksinin (\%43.7) dördüncü ekim zamanı ve ikinci ekim normundan, en düşük hasat indeksinin (\%33.3) ise dördüncü ekim zamanı ve dördüncü ekim normundan elde edilmiştir.

\section{Gözlemlenen Parametrelerin Korelasyon Matrisleri}

Çizelge 4'te görüldüğü gibi bitki boyu ile toplam dal sayısı arasında negatif ve önemsiz $(r=-0.257)$ bir korelasyon saptanırken, bin tane ağılığı $(r=0.276)$, biyolojik verim $(r=0.047)$ ve hasat indeksi $(r=$ 0.01 ile pozitif ve önemsiz bir ilişki saptanmıştır. Aynı şekilde bitkide toplam dal sayısı ile bin tane ağırlığı $(r=0.408)$ arasında pozitif ve önemsiz bir korelasyona sahipken, biyolojik verim $(r=-0.228)$ ve hasat indeksi ile $(r=-0.019)$ negatif ve önemsiz bir ilişki saptanmıştır. 1000 dane ağılığı biyolojik verimle $(r=-$ 0.036) negatif ve önemsiz bir korelasyona sahipken, hasat indeksi $(r=0.291)$ ile arasında pozitif ve önemsiz bir ilişkiye sahip olduğu saptanmıştır.

Tohum veriminin bitki boyu ile pozitif $\left(r=0.630^{\star *}\right)$ anlamlı ve \%40 doğrusal $\left(r^{2}=0.397\right)$ kuvvetli bir korelasyona sahip olduğu görülmektedir (Şekil 2A). Bununla birlikte, tohum veriminin bin tane ağırlığı ile anlamlı ve kuvvetli bir pozitif korelasyona sahip olduğu ( $r=0.650^{\star \star}$ ) (Çizelge 5) ve \%42 doğrusal bir ilişkiye $\left(r^{2}=0.423\right)$ sahip olduğu tespit edilmiştir (Şekil 2B). Biyolojik verim ile hasat indeksi arasında pozitif ve önemsiz ( $r=0.183$ ) bir ilişki saptanmıştır (Çizelge 5$)$. 
Tekin ve ark., Diyarbakır Ekolojik Koşullarında Kişniş (Coriandrum sativum var. microcarpum DC.) için Uygun Ekim Zamanı ve Ekim Normu Belirlenmesi

Çizelge 5. Kişnişte bitki boyu, toplam dal sayısı, biyolojik verim, tohum verimi, bin dane ağırlığı ve hasat indeksi özelliklerine ilişkin korelasyon kat sayıları ve önemlilik dereceleri.

Table 5. Correlation coefficients and significance degrees of coriander plant height, total number of branches, biological yield, seed yield, thousand grain weight and harvest index characteristics.

\begin{tabular}{lcccccc}
\hline Özellikler & BB & BTDS & BDA & TV & BV & HI \\
\hline Bitki boyu (BB) & 1 & -0.257 & 0.276 & $0.630^{* *}$ & 0.047 & 0.173 \\
Bitkide toplam dal sayısı (BTDS) & & 1 & 0.408 & 0.246 & -0.228 & -0.019 \\
Bin dane ağırlığı (BDA) & & & 1 & $0.650^{* *}$ & -0.036 & 0.291 \\
Tohum verimi (TV) & & & & 1 & 0.067 & 0.209 \\
Biyolojik verim (BV) & & & & 1 & 0.183 \\
Hasat indeksi (HI) & & & & & \\
\hline
\end{tabular}

*. Korelasyon 0.05 düzeyinde önemlidir.

**. Korelasyon 0.01 düzeyinde önemlidir.
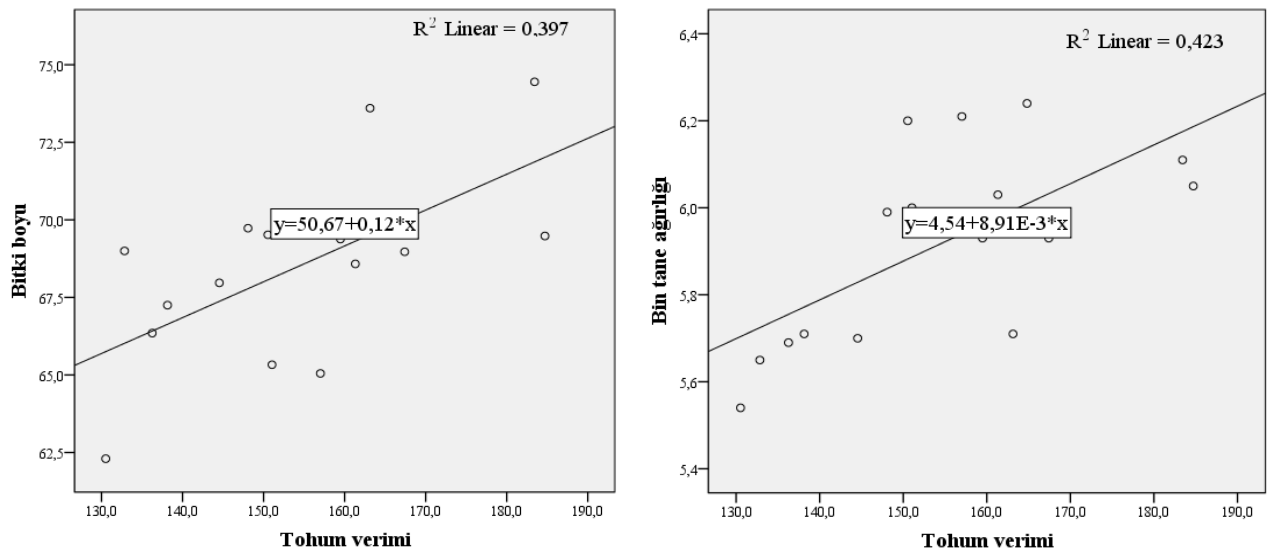

Şekil 2. Tohum verimi ile istatistiksel olarak önemli korelasyona sahip özellikler arasındaki basit dağılım grafiği Figure 2. Simple scatter plot between seed yield and traits with statistically significant correlation.

\section{SONUÇ}

Diyarbakır koşullarında kişniş bitkisinde farklı ekim zamanı ve ekim normlarının kişnişin verim ve bazı verim unsurları üzerine etkisini incelemek amacıyla yürütülen üç yıllık çalışma sonucunda; farklı ekim zamanlarının tohum verimi üzerine anlamlı bir etkisi olurken en yüksek tohum veriminin birinci ekim zamanından (kışlık ekim) alındığı ekim zamanı geciktikçe tohum veriminin düştüğü saptanmıştır. Çalışmada farklı ekim normunun ise tohum verimi üzerine olumlu bir etkisinin olmadığı saptanmış, en düşük ekim normunda bile birim alanda yeteri miktarda bitki yoğunluğu elde edildiğinden ve bu bitkilerin meyve ile sonuçlanan dal sayılarının diğer ekim normlarına göre daha yüksek olması birim alanda bitki sıklığı artınca dal sayılarına paralel olarak azalan meyve sayısı nedeniyle ekim normları arasında herhangi bir fark saptanmamıştır. Sonuç olarak Diyarbakır ekolojik koşullarında kişniş için en uygun ekim zamanı sonbahar veya kışlık ekim (18 Ekim - 24 Aralık) ve en uygun ekim normunun ise $3 \mathrm{~kg}$ $\mathrm{da}^{-1}$ olduğu tespit edilmiştir.

\section{ÇIKAR ÇATIŞMASI}

Yazarlar arasında herhangi bir çıkar çatışması mevcut değildir.

\section{YAZAR KATKISI}

Fethullah TEKIN arazi ve laboratuvar çalışmalarının yürütülmesine, Tamer ERYiĞiT istatistik analizlerinin yapılması ile makalenin yazılmasına ve Murat TUNÇTÜRK makalenin yazılmasına katkı sağlamışlardır. 


\section{KAYNAKLAR}

Baydar, H. (2005). Tıbbi, Aromatik ve Keyf Bitkileri: Bilimi ve Teknolojisi. SDÜ Yayınları. Yayın No: 51, Isparta.

Bhuiyan, M. N. I., Begum, J., \& Sultana, M. (2009). Chemical composition of leaf and seed essential oil of Coriandrum Sativum L. from Bangladesh. Bangladesh Journal of Pharmacology, 4(2), 150-153.

Carrubba, A., la Torre, R., Saiano, F., \& Alonzo, G. (2006). Effect of Sowing Time on Coriander Performance in a Semiarid Mediterranean Environment. Crop Science, 46(1), 437-447.

Davis, P. H. (1984). Flora of Turkey and East Aegean Island Vol: 4, Edinburg Universty Pres.

Died Erichsen, A., 1966. Result of characterization of germplasm collection of coriander (Coriandrum Sativum L.) in the Gatersleben genebank. Inter. Symp. Breeding Res. on Med. and Aromatik Plants, JQuedlinburg Germany.

Ghobadi, M., \& Ghobadi M. (2010). the effects of sowing dates and densities on yield and yield components of coriander (Coriandrum sativum L.). International Journal of Agricultural and Biosystems Engineering, 4(10), 725 728.

Katar, D., \& Kara N. (2016). Bitki sikliğinin iki farkli kişniş (Coriandrum sativum L.) çeşidinde verim ve verim unsurlari üzerine etkisinin araştirilmasi. Uluslararası Tarım ve Yaban Hayatı Bilimleri Dergisi, 2(1), 33-42.

Kaya, N., Yılmaz, G., \& Telci, İ. (2000). Farklı zamanlarda ekilen kişniş (Coriandrum Sativum L.) populasyonlarinin agronomik ve teknolojik özellikleri. Turkish Journal of Agricuture and Forestry, 24, 355-364.

Moosavi, G., Seghatoleslami, M., Ebrahimi, A., Fazeli, M., \& Jouyban, Z. (2015). The effect of nitrogen rate and plant density on morphological traits and essential oil yield of coriander. Journal of Ornamental Plants, 3(2), 95-103.

Özel, A., Güler, İ., \& Erden, K. (2009). Harran Ovası koşullarinda farkli ekim zamanlarinin kişniş (Coriandrum Sativum L.)'in verim ve bazi bitkisel özelliklerine etkisi. Harran Üniversitesi Ziraat Fakültesi Dergisi, 13(4), 41-48.

Tunçtürk, M. (2006). Kişniş (Coriandrum Sativum L.) bitkisinde farkli tohumluk miktarlarinin verim, verim özellikleri ve uçucu yağ orani üzerine etkisi. Selçuk Üniversitesi Ziraat Fakültesi Dergisi, 20(39), 58-62.

Uzun, A., Özçelik, H., \& Özden, Y. S. (2010). Orta Karadeniz Bölgesi İçin geliştirilen kişniş (Coriandrum Sativum L.) çesitlerinin bazi tarimsal özelliklerinin belirlenmesi, verim ve uçucu yag oraninin stabilite analizi. Gaziosmanpaşa Üniversitesi Ziraat Fakültesi Dergisi, 2010(1), 1-8.

Zheljazkov, V. D., Pickett, K. M., Caldwell, C. D., Pincock, J. A., Roberts, J. C., \& Mapplebeck, L. (2008). Cultivar and sowing date effects on seed yield and oil composition of coriander in Atlantic Canada. Industrial Crops and Products, 28(1), 88-94. 